\title{
Land Tenure, Alienation and Foreign Investment in the Pacific
}

David L Callies" and Michael B Dowling"*

\section{Introduction}

How can economic development in the Pacific coexist with indigenous property rights in land? Assuming that indigenous people and their governments want economic development and many Pacific states must rely upon outside investment, ${ }^{1}$ how can strictures on land alienation be utilised as a tool to control growth while attracting qualified investors by offering some measure of security, rather than as a weapon to fend off outsiders? Whether an investment is a mega-resort development or a copra plantation, foreign investors do not react favourably toward alienation restrictions and tenuous land rights. The tension between the preservation of 'native' land rights and the desire for development remains both critical and unresolved. ${ }^{2}$

The stakes involved in the playing out of these conflicts can be sizeable and dramatic. The claim filed recently in Melbourne by 16,000 Papua New Guinea villagers living along the Ok Tedi River seeking AUD $\$ 3$ billion in damages from the foreign owner of an upstream gold and copper mine demonstrates the potential for conflict between foreign investors and indigenous landholders. ${ }^{3}$

It is a major premise of this paper that the following are critical to secure foreign investment in land-based commercial ventures, always provided that such ventures are truly welcome in the relevant Pacific country:

(1) A system of title registration so that the investor can be certain who or what it is that can provide whatever interest in land is necessary for a commercial venture to succeed;

* This article is based on a paper first presented at the 25th Biennial Conference of the International Bar Association, section on General Practice, Committee 1, Real Property, in Melbourne, Australia, 5-9 October, 1994. Proceedings from that conference have been published and are available from the IBA, 2 Harewood Place, Hanover Square, London WIR 9HB, England.

** Benjamin A Kudo Professor of Law, William S Richardson School of Law, University of Hawaii at Manoa; JD, University of Michigan; LLM, Nottingham University.

*** Class of 1996, William S Richardson School of Law, University of Hawaii at Manoa; member, University of Hawaii Law Review. 
(2) An identification of whom among multiple owners is empowered to transact for a tribe or clan; and

(3) A secure interest in land of sufficient duration.

It is a conclusion of this paper that a Torrens or land court system is among the most effective ways to accomplish the first objective; a native trust, commission or corporation can efficiently serve the second; and some form of land trust is probably the most effective way to accomplish the third. What follows is a brief survey of land tenure, registration and foreign land interest investment/ownership patterns in selected Pacific countries, followed by a more detailed exploration and analysis of particular trust arrangements.

\section{Registration and Security of Tenure: A Necessary Prerequisite}

\section{A. Problem: Who Owns What?}

Perhaps the most basic obstacle in providing security in land-based transactions is identification of the relevant piece of land. 'The determination of land rights presupposes that the land parcels associated therewith have been defined either prior to or concurrent with the ascertainment of those rights.' 4 Whether on a sandy atoll or the floor of a rain forest, the land must first be accurately described.

The identification of a parcel of land in traditional Pacific societies is certainly no easy task. Boundaries marked by slashes on trees and the planting of special shrubs, for example, were common methods among many that have changed over time. ${ }^{5}$ Courts are forced to decide boundary disputes upon such meager and uncertain circumstantial evidence as high water marks, points on a stone wall 'long since forgotten' ${ }^{6}$ and a straight line of coconut palms.

However, since there was no written documentation in traditional societies, even when definite physical markings for boundaries existed, their relevance depended upon the memories of tribal leaders. For example, Maori youths of senior families were thoroughly instructed in boundary lore as part of their education, requiring the perfect memorisation of significant land features and markers. ${ }^{8}$ A modern 'perfect memorisation' in writing of exactly what parcel of land is in question and certified correct by an administrative agency or land court is the necessary first step in providing security for commercial investment in land.

Besides the problems associated with unsurveyed or poorly monumented traditional land, old land records have often been lost or destroyed. In American Samoa, the building housing the Fono (legislature) burned down in 1970, destroying legislative records concerning land matters. ${ }^{9}$ In many of the states that were formerly part of the Trust Territory of the Pacific, 
records, such as the land listings for the Airai state of Palau, fell victim to the chaos of World War II. ${ }^{10}$

Although systematic registration is preferable to sporadic registration, economic constraints as well as the complicated nature of the task usually lead to the systematic registration of only scattered plots of land. " Despite the availability of computerised databasing, land registration can be a time-consuming and costly undertaking. For example, the World Bank and the Indonesian government are planning a land registration project forecast to be completed in 25 years. ${ }^{12}$ On the cost side, it has been estimated that between 1986 and 2000, $\$ 90$ billion will be spent in the United States on the collection and management of spatially related information and that Canada annually expends $\$ 50$ per capita on surveying and mapping. ${ }^{13}$ Developing countries in the Pacific cannot bear such costs unassisted.

\section{B. Solution: Torrens Registration with Land Court}

A registration system used in Fiji, as well as in New Zealand, Hawaii, American Samoa, Papua New Guinea and, to some extent, the Solomon Islands, is based on the Australian Torrens system. ${ }^{14}$ Essentially, the Torrens system is a land registration system used to verify the ownership of land and establish the status of the title without the necessity of further search of public records beyond the certificate of title. Since 'its purpose is to establish an indefeasible title free from all rights or claims not registered with the registrar of title, ${ }^{15}$ it is ideally suited for the purposes of identifying those with an interest in land with some finality, if coupled with a land court.

The key factor in a Torrens system used in tandem with an adjudicative process is that it can provide a conclusive and final determination of title that can be guaranteed by the state, thus providing security for all parties to any land transaction. In a system using only registration of deeds and other land-related instruments such as mortgage documents, there is no such guarantee. In a Palauan case involving clan rights to disputed land, where the plaintiff argued that his recorded deed of transfer should defeat the defendant's claim of oral transfer, the court held that the written deed was invalid because it attempted to grant an interest the grantor did not have and that the recorded deed was no more effective than an oral transfer in a state with no statute of frauds requiring a written instrument. ${ }^{16}$ Registration of an invalid deed does not make it any more valid.

Contrast the results where a Torrens/land court system is well-established. Twenty-one of the states in the US adopted some version of the Torrens system by legislation (primarily between 1895 and 1917), ${ }^{17}$ although apparently only a handful actively use it today. (Indeed, nearly one-third of the 21 have subsequently repealed their statutes. $)^{18}$

Hawaii's system is particularly useful as an example because it is state-wide in application (most US mainland jurisdictions permit local governments to utilise the system, rather than 
require state-wide use). It also provides for a judicial process - through a land court - to establish title at the time of registration. This should be a prerequisite to establishing such a system in the Pacific, particularly in emerging Pacific Island countries. Nearly 2,000 decrees with title certificates have been issued by the land court in Hawaii since the commencement of the process in 1903, covering over 500,000 acres of land (approximately 13 per cent of the land area of the state). ${ }^{19}$

The process in Hawaii is succinctly and clearly described in a recent report of the State of Hawaii's Legislative Reference Bureau (LRB):

The process for registering land begins with an application to the Land Court by one or more persons who claim to own property in fee simple. The application must be accompanied by a map or plan of the land, and a complete abstract of title of the land as prepared by a title company, and must follow a prescribed form as to contents, signatures, etc. The Land Court registrar, upon acceptance of these papers, refers the application to a court-appointed examiner of title who after searching records, presents a certificate of the examiner's opinion upon the title of the property. Simultaneously, the registrar sends the map to the Department of Accounting and General Services (DAGS) for a state surveyor to verify the accuracy of the map. This verification is done by a ground check of the property boundaries. If both the examiner of title and DAGS surveyor issue favorable opinions, the application proceeds to the judicial process of notice, and hearings in the Land Court. Notice is given by registered mail, publication, posting, and any other means the court deems proper. Individuals and other parties including the State or county, may dispute the applicant's claim at court hearings.

Determination of title is decreed by the Land Court judge when the judge finds that the applicant has title and it is proper for registration. If the applicant's title is encumbered, for example, by a mortgage, the decree is issued subject to any current encumbrances. Thereupon, 'every decree of registration of absolute title shall bind the land and quiet the title thereto, subject only to the exceptions stated in section 50182. ${ }^{20}$

The registration itself takes place as follows:

The decree is transcribed in the registration book and an exact duplicate of the original certificate with the words 'owner's duplicate certificate' is delivered to the owner. Except for other miscellaneous provisions covered in sections 501-81 through 501-89, Hawaii Revised Statutes, the new owner of registered land probably will now have only limited future dealings with the Land Court. For example, if the owner's copy of the certificate of title has been lost, a petition to the Land Court is required in order for a new owner's duplicate to be issued by the BOC (Bureau of 
Conveyances). Once a parcel has been registered in the Torrens system, it cannot be removed and placed back into the regular system. Thus, any subsequent transfer of the property will be recorded in the land court registration branch and not in the regular system branch of the BOC..$^{21}$

The Hawaii statute is exhaustive and encyclopedic, dealing specifically with such transactions as registration of mortgages, foreclosures, leases, trust transfers, partitions, bankruptcy, eminent domain and agreements of sale. The State of Hawaii guarantees titles recorded in the land court system, compensating anyone who sustains loss or damage (or is deprived of land) as a consequence of error in the registration book, out of a statutory recovery fund (funded by a levy on registration, based upon the value of the land so registered). ${ }^{22}$ However, only one claim (for $\$ 110,000$ in 1986) has been successful. ${ }^{23}$ Costs associated with registration are not excessive (estimated in 1975 to be about $\$ 5,000$ ) but the process now takes several years, and accordingly has fallen into disuse. ${ }^{24}$ Running the registration system presently takes about 70 per cent of the time of five clerks, at a cost of about US $\$ 1$ million a year. ${ }^{25}$

In addition to a Torrens registration/land court system, a state might consider the longterm benefits of incorporating all the information in a computerised database. In New Zealand, the Department of Survey and Land Information has set up a Land Information System (LIS) which includes indices to regular certificates of title and Maori Land Court titles as well as to parcel plans, digitised boundaries and valuation records. ${ }^{26}$ The Maori Land Court has experimented with conversion of title documents to electronic images for storage as computer data in the National Archives for improved land management. ${ }^{27}$

In Hawaii, the City and County of Honolulu has so far spent $\$ 6$ million on a Geographic Information System (GIS), which presently has 30 layers of data including property ownership, census figures, water and sewer lines, zoning maps, etc. ${ }^{28}$ Not only will such computerised records be invaluable for quickly and accurately determining real property ownership information, but use of such a system for tax collection, zoning and planning, coastal zone management and infrastructure assessment also means the cost of setting up can be spread among a number of city or state governmental agencies.

The importance of establishing a professional and reliable surveying and registration system has been recognised in the Republic of the Marshall Islands. ${ }^{29}$ In fact, even though the Constitution provides that customary law shall be the authority in land matters, the Marshall Islands High Court has held that professional surveys are conclusive evidence in adjudicating boundary disputes and these matters will not be referred to traditional leaders for decisions. ${ }^{30}$ In Fiji, approximately 94 per cent of the land has been surveyed, registered and boundary mapped, ${ }^{31}$ both providing security for title and establishing a valuable database utilised by the Native Land Trust Board to plan development. 
Such technological solutions may not, of course, be feasible or affordable depending on circumstances. If systematic registration of all land is not economically feasible, proactive planning should at least ensure that areas suitable for development are selected and prioritised. Such was the case in a recent land-titling project in Thailand, where previously 15 per cent of all land was held by title deed, 52 per cent by certificates permitting various uses, while the rest was undocumented. ${ }^{32}$ With cost a major consideration, the programme identified four factors in prioritising registration: good title needed for securing credit for agriculture, unusually large amounts of undocumented parcels, relation to rural poverty eradication programmes and high incidence of boundary disputes. ${ }^{33}$ Similarly, any developing country can identify likely development areas, whether they be for golf courses or seafood processing plants, and give them priority for surveying and title registration.

At the very least, however, a land system that will provide security of tenure for investment purposes requires an accurate registration system such as Torrens, coupled with a conclusive adjudicative process that satisfies notice and due process concerns.

\section{Identification of Parties Authorised to Transact Land Ventures}

\section{A. Problem: Multiple Owners}

Determination of ownership, or at least who has the right to make decisions regarding the land, can be most troublesome in many of the Pacific nations. Preceding any constitutionally based alienation restrictions on land were the culturally based limitations that existed in the traditional tenure systems. ${ }^{34}$ Although customary land tenure in the Pacific islands is frequently described as 'communal,' one commentator rejects the blanket use of the term since it fails to recognise the 'diverse nature and complex structure of the rights held by various individuals and groups within the society. ${ }^{35}$ It would be more appropriate to characterise the land as being held concurrently, with a multiplicity and overlapping of individual rights. Indeed, the status within the traditional land system was constantly allocated according to such factors as line of descent, residence, occupation, affiliation, need and use. ${ }^{36}$

The basic concept of what land is also figures prominently in this discussion. Many 'Western' minds usually perceive land as a commodity or the primary resource from which wealth is derived ${ }^{37}$ In contrast, most indigenous cultures view land as something greater. New Zealand's Te Ture Whenua Maori Act 1993 refers to land as 'taonga tuku iho' — a 'treasure of immense cultural and spiritual value which has been passed from generation to generation. $^{38}$

Complexity of succession rights in land is another problem. For example, in many Pacific island cultures, matrilineal succession rights predominated. However, as one Trust Territory 
court noted in a Palauan case, after contact with colonial administrations, individual land ownership was introduced to provide for patrilineal inheritance. ${ }^{39}$ In the Cook Islands, early land court judges modified customary succession rights to allow secondary members of a lineage to be granted primary lineage rights with an increasingly fragmentary effect on land titles. ${ }^{40}$ Thus, the problem of 'ownership' determination was exacerbated in some societies because of the combination of native and Western systems allocating rights through family descent, which resulted in extreme fragmentation with potentially more than 100 owners sharing title to a single parcel of land. ${ }^{41}$

This multiplicity of ownership resulted in one lease negotiation in the Cook Islands requiring the lessee to contact every one of the 99 'owners,' only 35 of whom lived on the same island. ${ }^{42}$ Even when in theory one leader is empowered to transact for the group, land courts have had to rule in disputes where no decision could be effected during a vacancy in a matai (Samoan chief) title, ${ }^{43}$ and where two or more persons were allowed to hold the same matai title. ${ }^{44} \mathrm{~A}$ disputed matai title could be adjudged on the basis of 'reputation in the community,' ${ }^{45}$ and custom still required family consultation before a decision involving land could be made. ${ }^{46}$ Palauan society also required consultation with 'strong' members of the clan or lineage. ${ }^{47}$ However, problems arose in determining who was 'strong' and one court was required to adjudicate a land dispute where one high-ranking leader was considered 'too weak-willed to act. ${ }^{\prime 48}$

A pointed example of ownership determination problems affecting land-based investment involved the proposed development of an ecotourist resort on Erikub Atoll in the Republic of the Marshall Islands. In the 'first serious, privately funded tourism venture to be planned in the Marshalls,' an American investor signed a $\$ 5$ million lease with one group of landowners. ${ }^{49}$ After delivery of construction materials, another group filed a lawsuit claiming paramount rights. In the end, the developer abandoned the project.

\section{B. Solution: The Native Trust or Corporation}

In conjunction with a conclusive land registration system defining the party or parties holding title to a particular piece of land, an entity such as a trust or corporation in cases where there are multiple ownership rights can work to the advantage of all concerned. Besides protecting the rights of the indigenous community, the native trust seems the logical device to make the decision-making in land matters both legitimate and efficient. The chief or tribal elder in essence acts as the trustee for the extended group; establishing a formal trust simply extends the same relationship. Indeed, the latest New Zealand legislation considers the named Maori landholder as a kaitiaki or custodian holding the land in trust for the collective benefit of the tribe and its descendants. ${ }^{50}$

During the 1930s in New Zealand, realising that many financially unsuccessful small plots could be combined into larger holdings for development or lease, Minister of 
Native Affairs Ngati incorporated his own tribe. ${ }^{51}$ Many other tribes followed suit. Maori tribal trusts are also plentiful and sizeable. Such trusts own 1.3 million hectares of land valued at about $\$ 1$ billion. ${ }^{52}$ Forming a trust or corporation representing tribal or family rights in land creates a legal entity with authorised decision-makers with which a foreign investor can reliably deal.

Formation of a trust or incorporation in New Zealand is necessary in order to lease Maori freehold land (for longer than three years) without approval of the Maori Land Court under the most recent legislation. ${ }^{53}$ The Te Ture Whenua Maori Act 1993 restricts all forms of alienation of Maori freehold land, including sales, leases (longer than three years), gifts, licences, mortgages, grants of sand and mineral rights, timber-cutting rights and milk-sharing agreements. ${ }^{54}$

However, the Act also attempts to streamline certain land transactions for trusts and incorporations to facilitate growth and development. The Act establishes five separate types of trust. ${ }^{55}$ Each addresses a different use. For example, a 'putea trust' can be established to manage land interests where fragmented administration is impractical or some owners cannot be located or identified. ${ }^{56}$

By using one of these trusts or through an incorporation (the new Act also now classifies these shares as interests in land), the native entity can bypass confirmation by the Maori Land Court in transactions other than outright sales or gifts (although leases longer than 42 years need approval). ${ }^{57}$ Alienation without the device of a trust or incorporation still requires Land Court approval, a lengthy and onerous process.

In Fiji, the 'native' trust is conceptually different. Rather than just representing an extended family or village community, the Native Land Trust Board controls all native land, about 3.7 million acres or 83.5 per cent of all land in Fiji. ${ }^{58}$ Currently, a comprehensive development plan for tourism in Fiji's northern island of Vanua Levu is being prepared 'significantly' by the Native Land Trust Board (NLTB), with the 'intention to base tourism firmly on Fijian culture and environment. ${ }^{59}$ The advantage of such extensive control is obvious: with such leverage over the land, the NLTB can ensure that the beneficiaries obtain the type of development they want. The benefit to the foreign investor is the security of dealing with the legal and established representative of the native landowners.

However, effective administration of these land interests is only as reliable as the trust managers. Commentators familiar with New Zealand's many trusts fault Maori incorporations and trusts for being poorly run, reactive and conservative since selection for management positions tends to be based on seniority and lineage rather than on business or management experience. ${ }^{60}$ 


\section{The Land Trust as a Mechanism for Land-based Investment}

In most, if not all, less-developed Pacific countries where the indigenous population has not yet been displaced by newcomers, restrictions on the ownership and alienation of land are common. Constitutional provisions typically restrict the selling, leasing and devising of land by citizenship, ${ }^{61}$ birth ${ }^{62}$ or race.$^{63}$ In the Cook Islands, for example, although some freehold land is available, customary or native-held land may be alienated only by way of lease, licence or easement for a maximum term of 60 years and then such transactions are subject to being confirmed by the Land Division of the High Court. ${ }^{64}$ Customary land may not be sold outright, nor can it be devised by will. ${ }^{65}$

Sections 4 and 5 of Article XIII of the Constitution of the Federated States of Micronesia restrict ownership of land and waters to citizens. Lease agreements for indefinite terms are prohibited. ${ }^{66}$ Corporations not wholly owned by citizens are also barred from acquiring land. ${ }^{67}$ However, Micronesia's four states have their own constitutions which further restrict land ownership. For example, while the federal constitution restricts land ownership to citizens, the Pohnpeian Constitution in Article 12 limits land acquisition to ' $p$ wilidak' - a 'true' citizen or 'child of the soil. ${ }^{68}$ Land restrictions have created such an obstacle to investment that one of the Micronesian government's proposed large-scale commercial projects in recent years has been the development of a hotel industry based on recommissioned cruise ships to serve as floating hotels - in large part because there would be no land tenure problems. ${ }^{69}$

In the Republic of the Marshall Islands, Article X of the Constitution provides that customary land may not be alienated or disposed of, "whether by way of sale, mortgage, lease, license or otherwise, without the approval of the Iroijlaplap (paramount chief), Iroijedrik (royalty of half-blood) where necessary, Alab (lineage elder) and the Senior Dri Jerbal (worker) of such land, who shall be deemed to represent all persons having an interest in that land.' 70 Article X also provides that nothing in Article II (Bill of Rights) shall be construed to invalidate customary law or traditional practice concerning land tenure. ${ }^{71}$ The High Court of the Marshall Islands has held that before filing any court action in a land matter, an attempt must first be made to obtain a decision from the Iroijlaplap. ${ }^{72}$

In Mexico, restriction of foreign ownership of land was embodied in the 1917 Constitution following the revolution of 1910. Because a main reason for the uprising was the resentment by 'peasants' of the wealthy large landholders, Article 27 of the Constitution established an ejido or communal land system whereby the government could confiscate privately held land for redistribution. ${ }^{73}$ However, ejido land occupants could not sell, lease or use the land as collateral either with respect to Mexican citizens or foreigners. ${ }^{74}$ This system was changed under President Salinas' 1992 free market reforms by amendment of Article 27 of the Constitution and private ownership of former ejido land is now permitted. ${ }^{75}$ Although 
foreign individuals may now own land with certain exceptions, authorisation from the Secretary of Foreign Relations is still required, although the permission formerly needed from the Secretary of the Interior is no longer necessary. ${ }^{76}$ However, restrictions regarding ownership of border and coastal lands, first promulgated in 1824 over fears of hostile activity in neighbouring Texas and its independence movement, are still in force. ${ }^{77}$

Although there is now a legal device approved by the Mexican government to 'bypass' the restriction (to be discussed infra), various outright illegitimate or at least questionable methods have arisen in attempts to circumvent the law. Most common has been the use of prestanombre or name-lending where the foreign would-be owner uses a Mexican citizen's name. As well as being illegal, it affords little security to the foreigner should the titleholding person die or refuse to cooperate. Other attempts to circumvent the law have included using successive and/or alternating leases (leases under ten years by foreigners are permissible), corporations with unregistered shares and double-tiered corporations. ${ }^{78}$ Apparently much of the foreign-sourced resort development of Acapulco was carried out under the last method. ${ }^{79}$

Racially based restrictions on land ownership exist in US territories as well. American courts have upheld such restrictions in decisions involving the laws in American Samoa and the Commonwealth of the Northern Mariana Islands (CNMI).

The Constitution of American Samoa in Article I, section 3 grants the legislature authority to pass laws against the alienation of land and destruction of ' $F a$ ' $a$ Samoa' — the Samoan way of life. ${ }^{80}$ The restriction as set forth by statute:

It is prohibited to alienate any lands except freehold lands to any person who has less than one-half native blood, and if a person has any nonnative blood whatever, it is prohibited to alienate any native lands to such person unless he was born in American Samoa, is a descendant of a Samoan, lived in American Samoa for more than five years and has officially declared his intention of making American Samoa his home for life. ${ }^{81}$

Any alienation, even to a qualified Samoan, requires the approval of the Governor ${ }^{82}$ Although freehold land is exempt from these conditions, there are only 1.6 square miles of freehold land in all of American Samoa today. ${ }^{83}$ The government has attempted to alleviate the problem of land availability to outside commercial investors by itself purchasing restricted land for long-term leasing to non-Samoans. However, so far, only one 90 -acre industrial park has been developed. ${ }^{84}$

Court decisions have continually upheld the validity of these restrictions on ownership. In one case, where the registrar refused to register a warranty deed conveying individuallyowned but native land to a Samoan woman and her non-Samoan husband and the couple 
challenged the statutory racial restriction, the High Court held the use of racial classification was constitutionally (referring to the U.S. constitution) permissible in order to safeguard a 'compelling historical and continuing interest in preserving the land and the culture of the Samoan people. ${ }^{85}$ In so ruling, the court quoted at length from an earlier decision also upholding the restriction:

Land to the American Samoan is life itself. ... The whole fiber of the social, economic, traditional, and political pattern in American Samoa is woven fully by the strong thread in which American Samoans place in the ownership of land. Once this protection is broken, once this thread signifying the ownership of land is pulled, the whole fiber, the whole pattern of the Samoan way of life will be forever destroyed. ${ }^{86}$

The source of much of the litigation presently occurring in the CNMI is the ownership restrictions found in Article XII of that constititution. In upholding the restrictions on leasehold interest, the Ninth Circuit Court of Appeals acknowledged their fundamental purpose:

The land alienation restrictions are properly viewed as an attempt, albeit a paternalistic one, to prevent the inhabitants from selling their cultural anchor for short-term economic gain, thereby protecting local culture arw. alues and preventing exploitation of the inexperienced islanders at the hands of resourceful and comparatively wealthy outside investors. ${ }^{87}$

However, the 'resourceful and comparatively wealthy outside investors' are often badly needed and wanted. How can they be afforded some security in a land-based investment and still remain within the parameters of the constitutional and statutory provisions that limit their interests?

\section{A. Solution 1: The Mexican Civil Law Trust}

Civil law states such as Mexico have made broad use of a legislatively enacted trust. In a civil law system, the advantage of legislative intervention in arriving at establishing the trust concept lies in resolving the peculiar structure of the trust with the demands of business dealings and the obstacles of existing legislation. ${ }^{88}$ Although a type of trust or fideicomiso existed under Roman law, it referred to testamentary and non-testamentary dispositions of an estate with instructions to an heir for further transfer to a third party. ${ }^{89}$ However, the modern civil trust found in most Latin American countries is based somewhat on the English common law trust. ${ }^{90}$

First recognised as a legal device in Mexico in 1924 under the General Law of Credit Institutions and Banking Establishments, the subsequent Trust Bank Laws of 1926 characterised the fideicomiso as an 'irrevocable agency. ' ${ }^{91}$ Although later legislation in 1932 
redefined the nature of the trust as an estate (patrimonio) rather than an agency, the concept of the actual transfer of title or ownership of the property to the trustee bank (fiduciaro) to be held for the benefit of the beneficiary (fideicomisario) was only established through subsequent decisions by Mexican courts. ${ }^{92}$ The beneficial interest is considered by Mexican law as a personal interest rather than a real interest..$^{93}$

Following the debt crisis of the 1970s and the critical need for foreign investment, the Mexican government gradually eased the alienation prohibitions in the restricted areas through approved use of the fideicomiso in otherwise restricted land acquisition. In particular, the fideicomiso has been well utilised to address the constitutional prohibition of alienating land to foreigners along the coastal and border areas. The restricted zones are within 100 kilometers of Mexico's land borders and within 50 kilometers of its coastline. ${ }^{94}$

The Decree of 29 April 1971 by President Echeverria recognised as 'imperative' the acceleration of industrial and tourist development in the restricted areas. ${ }^{95}$ Because the trust device only permits the temporary use and enjoyment of the property while the legal title resides with the fiduciary, the decree approved the use of the fideicomiso as a constitutionally legitimate solution. ${ }^{96}$ The substance of the decree regarding the fideicomiso in land acquisition was later made part of the 1973 Foreign Investment Law ${ }^{97}$ and required two conditions: $t$ he property was to be used for industrial or tourism purposes and the express acknowledgement that no ownership rights accrued to the beneficiary. ${ }^{98}$ After applying to set up a trust with a Mexican credit institution, the fiduciary would request authorisation from the Ministry of Foreign Affairs. ${ }^{99}$ Other rules of the 1973 law were: only a Mexican credit institution could serve as trustee, the trust period was limited to 30 years, the fiduciary trustee needed to maintain continuous title to the property, the trustee could not lease the property for longer than ten years and, upon expiration of the trust, ownership could only be conveyed to a lawfully authorised purchaser. ${ }^{100}$

The 1973 Foreign Investment Law was liberalised by regulations promulgated in $1989 .{ }^{101}$ The new regulations provide a list of minimal qualifications that, if complied with, obliges the Ministry of Foreign Affairs to approve the fideicomiso within 45 days. ${ }^{102}$ In addition, the term of the trust is now renewable for another 30 years if the beneficiaries remain the same, the trust conditions are the same, the extension request is made within 181 to 360 days prior to termination, and all other provisions of the Foreign Investment Law are followed. ${ }^{103}$ The trust agreement permits use of the land and any proceeds the trustees may obtain from it, including sale of the land. ${ }^{104}$ In addition to the existing system, similar provisions for the fideicomiso system were recently written into the North American Free Trade Agreement whereby the investors are issued 'certificates of participation' with similar terms as described above. ${ }^{105}$

Although in areas outside of the restricted coastal and border areas individuals may now purchase land (with government approval), foreign corporations are still barred from 
ownership rights. ${ }^{106}$ However, the fideicomiso is authorised for use in interior land acquisition. These trusts provide the foreign corporation with land-use rights that would otherwise require establishing a foreign-owned Mexican company. If the land is not in the restricted zone, no special government approval is needed. ${ }^{107}$

\section{B. Solution 2: The Common Law Land Trust}

Originating as a common law device in England as a legal response to the Statute of Uses (1536), the land trust should theoretically be a legitimate instrument throughout states following English common law. Its most relevant feature for foreign investment purposes is that both legal and equitable title are vested in the trustee and the beneficiary has no interest in either. ${ }^{108}$ The owner of a beneficial interest in a land trust has four basic powers: to possess and physically control the estate, receive any generated income, direct the trustee in dealing with title and receive the proceeds when sold. However, the beneficiary has no legal or equitable right, title or interest:

The land trust is limited to an arrangement by which the trustee holds title to the property and all active managerial and administrative powers are reserved to the beneficiaries. The trustee's only duty is to deal with the trust when and as directed by the beneficiaries, and to convey the property, or to cause it to be sold, when the trust terminates. ${ }^{109}$

Among the benefits offered by the traditional land trust are:

(1) privacy of ownership, although disclosure can be required by statute;

(2) limited exposure to judgments and liens;

(3) avoidance of marital interests in title;

(4) transferability of beneficial interest by simple assignment; and

(5) use of beneficial interest as collateral. ${ }^{110}$

Because of its utility in solving the ownership interests problem prevalent in many Pacific nations, the land trust - particularly that version known as the Illinois land trust — is worth examining in some detail. What follows is a summary of the salient features of the law authorising such trusts in Hawaii, followed by a summary of the key features of the documentation."'"

A potentially critical issue is the creation of a local entity which holds both legal and equitable property interests, in order to avoid violating restictions on foreign ownership. While the statute is usually used to transfer full fee simple interests, lesser interests could be so transferred as well: 
Any recorded instrument transferring any interest in real property in this state, including but not limited to leasehold and mortgage interests, to any person, corporation, bank or trust company, qualified to act as trustee in this state ... shall be effective to vest in the trustee full rights of ownership over the real property or interest therein, with full power and authority as granted and provided in the recorded instrument to deal in and with the property or interest therein or any part thereof.

A subseqent section declares that anyone 'dealing' with the trustee as owner takes the property free of any of the interests of the beneficiary:

Any person dealing with the trustee under the recorded instrument shall take any interest transferred by the trustee free and clear of the claims of all the beneficiaries of the trust, and of any unrecoded separate declarations or agreements collateral to the unrecorded instrument whether referred to in the recorded instrument or not, and of anyone claiming by, through or under such beneficiaries ....

The potential here, of course, is to reduce the importance of a recording system as outlined in Part II, though it remains a fundamental conclusion of this paper that such a recording system is a prerequisite for the reasons noted in a preceding section. The beneficiary of the trust - usually the owner of the property interest until the creation of the trust - controls the trust to the extent set out in the trust documents.

Most critically, the beneficial interest is now defined as personal, and not real property, which would presumably free it from the reach of laws preventing the foreign ownership of long-term interests in real property:

In all cases where the recorded instrument contains a provision defining and declaring the interest of beneficiaries to be personal property only, the provision shall be controlling for all purposes where the determination shall become an issue under the laws or in the courts of this state.

Trust agreements executed pursuant to the Illinois land trust statutory scheme generally make clear that the trustee acts only upon the direction of the beneficiaries in accordance with instructions contained in the trust agreement. For example:

It is understood and agreed by the parties hereto and by any person who may hereafter become a beneficiary hereunder that the bank as trustee will deal with said real estate and with any cash or other property or assets of any kind which may come into the possession or control of the Trustee only when authorized to do so in writing, and that it will make deeds for or mortgages or trust deeds (including the waiver of the right of redemption from sale under an order or decree of foreclosure) or otherwise deal 
with the title to said real estate or such other assets or property on the written direction of such person or persons as may be the beneficiary or beneficiaries at the time, or on the written direction of [any two of the following persons - here name persons] or such other person or persons as shall be from time to time named in writing by the beneficiary or beneficiaries.

Further standard language makes it clear that it is the beneficiaries who manage the assets of the trust and not the trustee:

The beneficiary or beneficiaries hereunder in his, her or their own right shall have the management of said property and control of the selling, renting and handling thereof and the bookkeeping, performing and enforcing of all leases and agreements and covenants running with the land, and each beneficiary or his or her agent shall collect and handle his or her share of the rents (etc).

While the purpose of the land trust, in Hawaii at least, was to formalise collections of individuals whose primary purpose was to acquire and dispose of land, providing for continuity of title regardless of the individual situation of the members of the group (litigation, death, etc), it is in many ways an ideal vehicle for the foreign investor in the Pacific who is seeking some security of tenure in an interest in land connected with a commercial venture.

\section{The Non-Solution: The Resulting Trust and the CNMI Litigation}

Coming under much scrutiny recently is the CNMI Supreme Court's use of the 'resulting trust' ${ }^{\prime 12}$ doctrine. Because the trustee of the resulting trust holds only the bare legal title for the benefit of the person who furnishes the consideration (and who the CNMI Supreme Court holds retains the equitable title), the court has held the exercise of an option agreement is illegal and void $a b$ initio. ${ }^{113}$

In the case of Ferreira $\mathrm{v}$ Borja,${ }^{114}$ where a purchaser who was of Northern Marianas (NMI) descent but who had entered into a partnership agreement with non-NMI descent persons concerning the land and sought to quiet title, the court likewise found a resulting trust and voided the sale. However, in a lengthy dissent, Special Judge King criticised the application as 'inherently suspect' and said that the 'novel effort has forced the Court to ignore or modify key aspects of the doctrine, and thereby to transmogrify the resulting trust doctrine itself.' 115 On appeal, the United States Court of Appeals for the Ninth Circuit essentially adopted Judge King's dissent. Since the resulting trust is implied in law and actually created by the court, '[i]t would be incongruous to use a court's equitable powers to create a resulting trust in favor of someone and then use the existence of the resulting trust as a basis for finding that that person has violated the law.' 116 
However, the focus of the CNMI court's decisions is on whether the equitable title is in essence held by the non-NMI descent person. As the CNMI Supreme Court asked in Ferreira:

The question is whether Diana [plaintiff] possesses both legal and equitable titles to the properties, or whether she is holding title in trust for the benefit of all the four partners. If the latter, did the three partners not of NMI descent acquire an equitable fee simple interest in the properties? If so, such violates Article XII. ${ }^{17}$

Assuming, therefore, that the holding of both legal and equitable title by a qualified NMI descent person (or corporation as set forth in Article XII, § 5) is the threshhold requirement in ascertaining the constitutional validity of a particular land transaction, a possible solution that could satisfy both the letter and the spirit of the law is the common law land trust as discussed above.

Although some of the CNMI lower courts analysed alleged Article XII violations in terms of control and a theory of agency, the CNMI Supreme Court has held that 'common law principles of trust are dispositive. "18 Holding the court to that line of reasoning seems to indicate a device such as the Illinois land trust would be judicially acceptable.

However, the land trust in Illinois is a product of decisional law and statutes were only recently enacted to modify its scope. Since the land trust commonly uses a banking institution as the trustee, the Illinois legislature enacted a statute addressing the powers and duties of a financial institution that is both a trustee and a lender to the same trust. ${ }^{119} \mathrm{As}$ in the case of Hawaii, the land trust has been validated through legislation as a statute. Of course, each jurisdiction can enact legislation necessary to regulate the particular application of the land trust, such as disclosure, assignability and, as would seem critical under the terms of Article XII, duration not exceeding 55 years.

The legislative enactment in the CNMI of a similar land trust system would certainly seem to meet the requirements of the constitutional provisions regarding alienation. Particular attention to such requirements as the 55-year limit on long-term leases as well as other details could be addressed. By writing new law, the legislature could set the parameters of what would be permitted, affording all parties the security of a presumptively valid lease or other transaction. ${ }^{120}$

However, as a reaction to the litigation and the threat of economic fallout from it, a bill attempting to solve the problems was signed into law in October 1993. What has become Public Law No. 8-32 directly resulted from the court decisions discussed above, a noticeable decline in land values and testimony indicating hotels had cancelled plans for expansion, as well as the fact that title insurers would no longer write new policies since title searches could no longer be considered conclusive. ${ }^{21}$ 
The main provisions of the new law are:

\$ 4917: Limitation on attorney's fees in an Article XII case to the lesser of 20 per cent of the fair market value of property involved, 20 per cent of the actual amount received by the client in the transaction, or billable hours multiplied by $\$ 700$.

§ 4918: Equitable adjustment to be paid to adversely affected parties in Article XII property cases, with fraud as the only exception to recovery.

$\S 4922$ : Where transfer of a real property interest is made to one person but the purchase price paid by another who is not constitutionally qualified, a resulting trust does not arise.

$\S 4931$ : Six year statute of limitations for Article XII challenges. ${ }^{122}$

The pertinent sections of the new law have yet to be used or challenged. However, there is discussion of a constitutional challenge with regard to a case currently under judicial review. ${ }^{123}$ In addition, November 1993 elections brought in a new administration, some members of which oppose the law as currently enacted since it 'provides restitution regardless of fault. ' ${ }^{24}$ Apparently one suggestion of the new administration is the establishment of a new land court that would review 'draft lease agreements' made between landowners and other parties which could be characterised as a pre-approval process affording some measure of security for the foreign investor. ${ }^{125}$ Such an arrangement, in conjunction with use of the trust mechanism (either the Mexican model or the common law land trust), would appear to be a viable solution to accomplishing the goal of providing sufficiently long-term security for the foreign investor as well as satisfying the constitutional provisions protecting the land rights of the CNMI's indigenous people.

\section{Conclusion}

There is no intrinsic imperative for states - emerging, developing, mature or developed to permit foreign ownership of interests in land. Indeed, there are many cultural, sociological and political reasons to limit ownership to indigenous peoples. However, as the random examples selected for this paper indicate, the economic effect on land-based foreign investment can be dramatic. It is arguable that there is an inherent tension between such limits and any economic development goals which are based upon such foreign investment. At least, such restrictions substantially impede such investment, to the detriment of economic development goals.

It is a major tenet of this paper that the best compromise between reserving a substantial measure of rights in real property to citizens and promoting land-based foreign investment 
is to provide for and guarantee investment-grade interests in property for foreign investors, leaving the basic fee or ultimate ownership of the land irrevocably in local hands. Such an investment-grade interest must have certain characteristics:

(1) it must be definite in terms of duration, location and character;

(2) it must be cognisable and secure at law and equity under the totality of the law of the state in which it is located; and

it must be recordable and recorded.

In sum, such an interest must be sufficiently secure that an investor will realise whatever return on investment is necessary to that investor to attract the investment. This also means the property interest is sufficiently cognisable by whatever is the source of money for the investment so that a lending institution is willing and able under the laws and business code of that institution's home state to securely lend sufficient funds for the investment.

Of the several alternatives discussed in this paper, it is a tentative conclusion that some form of land trust best serves the multiple needs and purposes of both the 'host' state and the foreign investor, coupled perhaps with an agency of local state government which facilitates or stands between the local 'owners' of real property and the potential investor. Such an agency should have the authority to bind such local owners to whatever terms of real property interest transfer are necessary to attract the investor. By further separating the legal title from equitable title, it should be possible to go so far as to avoid the reach of limitations on real property ownership entirely, as is apparently the situation with the Illinois land trust. A presupposition to all of the above is that some responsible and probably public institution like a land court will have made a binding determination of who has legally cognisable property interests in a given parcel of land, and will have provided some means of permanently and clearly recording such a determination by means of, for example, a Torrens certificate of title.

The complex problem of attracting foreign investment in land-based enterprises while preserving local property rights demands complex solutions. However, to fail is to almost certainly have one without the other. To many nations of the Pacific, this is an unacceptable choice.

\section{ENDNOTES}

1 AP Thirwall, The Performance and Prospects of the Pacific Island Economies in the World Economy (1991). The commentator points out the obstacles to growth in a small island economy: lack of diversification leaving the economy vulnerable to internal and external shocks; vital infrastructure such as roads, public health facilities and utilities do not become 'economical' until the population has grown to a certain level; and geographic remoteness significantly impacts transportation and communication costs. Ibid, $\mathrm{p} 6$. To overcome these inhibiting factors, foreign direct investment becomes desirable since (1) it adds directly to productive 
capital and is much less volatile than financial capital, and (2) it is a 'non-debt' creating flow without predetermined repayment obligations. Ibid, $\mathrm{p} 25$.

2 One Pacific area economist has found the most common concern of the region's government officials to be 'how not to become another Honolulu or another Guam.' Interview with WM Osman, PhD, vice-president and economist, Bank of Hawaii, in Honolulu (29 June 1994). In contrasting Hawaii with Fiji, the bank's own publication described Hawaii's condition: 'unrestricted foreign real estate speculation has been intense and has given rise to a variety of land use pattern distortions and unproductive holdings.' Bank of Hawaii, An Economic Assessment of Fiji (1993) p 8. Indicative of such a concern are the words of South Pacific Commission Secretary-General Panraoi Baiteke: 'What the people are stuck with are the less nicer things, like environment degradation, growing rates of malnutrition, congested urban centers, rising crime rates, broken families and many other sadder outcomes of change.' 'Go Slow in Change, SPC Leader Advises Nations', Pacific, Jan/Feb 1993, p 12.

'Villagers Sue Over Dying River, Way of Life' Honolulu StarBulletin, 11 July 1994, p A9.

4 PF Dale and JD McLaughlin, Land Information Management: An Introduction with Special Reference to Cadastral Problems in Third World Countries (1988) p 31.

5 NJ Pollock, 'Landholding on Namu Atoll, Marshall Islands in Land Tenure' in Oceania, p 105 (1974; ed Lundsgaarde).

6 Vaivao v Craddick (1990) 14 ASR 108, at p 110.

7 Faleafine v Suapilimai (1988) 7 ASR 108.

8 IH Kawharu, Maori Land Tenure: Studies of a Changing Institution (1977) p 60.

9 W Stewart 'Land Tenure in American Samoa' (1973) 10 Hawaii Bar Journal 54.

10 Riumd v Tanaka (App Div 1989) I ROP Intrm 597, at p 598.

11 RG Crocombe, Registration in the Pacific Islands: Experiences and Potentials in Land Tenure and Rural Productivity in the Pacific Islands, pp $41-42$ (1984; eds Acquaye \& Crocombe).

12 'Indonesia: Hungry for Land' The Economist, 5 Mar 1994, p 39.

13 Dale, op cit $\mathrm{n} 4, \mathrm{p} 2$.

14 See generally, South Pacific Islands Legal Systems (1993; ed Ntumy).

15 JK Mardfin, Legislative Reference Bureau, Two Land Recording Systems: Report No 7, 1987 (1987) p 4.

16 Llecholech v Blau, 1 TTR 525, at pp 528-29 (HCTT Tr Div 1974).

17 Illinois (1895), Ohio (1896), California (1897), Massachusetts (1898), Minnesota (1901), Oregon (1901), Colorado (1903), Hawaii (1903), Washington (1907), New York (1908), North Carolina (1913), Mississippi (1914), Nebraska (1915), Virginia (1916), South Carolina (1916), Georgia (1917), Tennessee (1917), North Dakota (1917), South Dakota (1917), Utah (1917). Mardfin, supra n 15, p 24.

18 Ibid.

19 Ibid, p 28.

20 lbid, pp 11-13.

21 lbid, p 14.

22 lbid, $\mathrm{p} 15$.

23 Ibid, $\mathrm{p} 30$.

24 Ibid, pp 30-37.

25 Ibid, pp 38-40.

26 Statistics New Zealand, New Zealand Official Yearbook 1994 p 322.

27 lbid, p 324.

28 R Borreca, 'Computer Whiz: City's New Map Tells It All' Honolulu Star-Bulletin, 3 Aug 1994, p A4.

29 The licensing and registration of professional surveyors is mandated by the Land Surveyors Registration Act (19 M I Rev C, Chap 3) and fines for interfering with boundary markers is set out in the Real and Personal Property Act (24 M I Rev C, Chap 1).

30 Reimers v Helkena, Civ Act No 1983-59 (1983).

31 Bank of Hawaii, An Economic Assessment of Fiji (1993) p 8.

32 Dale, op cit $\mathrm{n} 4, \mathrm{p} 43$.

33 lbid, p 44.

One commentator describes the ownership of land in Pacific societies as an 'ancestral estate' - a merger of a fee tail and life estate. 'There are no societies in Oceania that can be said to allow persons to hold a fee simple estate interest in land ... The most compelling evidence against the recognition of the fee simple interest resides with the universally recognised limitation on alienation, that is, landowners cannot dispose of their lands as they please.' HP Lundsgaarde, 'Pacific Land Tenure in a Nutshell in Land Tenure' in Oceania (1974; ed Lundsgaarde) pp 270-71. 
35 RG Crocombe, Land Tenure in the Cook Islands (1964) $\mathrm{p} 39$. citation

36 RG Crocombe, 'An Approach to the Analysis of Land Tenure Systems in Land Tenure' in Oceania (1974; ed Lundsgaarde), pp13-14.

37 Dale, op cit $\mathrm{n} 4, \mathrm{p} 227$.

38 Te Puni Kokiri (Ministry of Maori Development), Te Ture Whenua Maori Act 1993: A Technical Discussion (1993) p 52.

39 Ngiruhelbad $\vee$ Merit (1958) I TTR 367, at p 369.

40 Crocombe, op cit $\mathrm{n} 35, \mathrm{p} 125$.

41 Crocombe, op cit $\mathrm{n} 11, \mathrm{p} 29$.

42 Crocombe, op cit $\mathrm{n} 35, \mathrm{p} 157$.

43 Fagasoaia v Fanene (1990) 17 ASR2d 91.

44 In re Matai Title Mulitauaopele (1990)16 ASR2d 63.

45 Seva'aetasi Family v Fanene (1988) 9 ASR2d 118.

46 Vaimaonoa $v$ Tuitasi (1991) 18 ASR2d 88.

47 Elechus v Kdseau I TTR 444, 45I (HCTT Tr Div 1969).

48 Techekii v Ngoriyakl I TTR 411, 412 (HCTT Tr Div 1963).

49 G Johnson, '100th Special Issue: Marshall Islands' Pacific, July/Aug 1993, pp 68, 70.

50 Te Puni Kokiri, op cit n 38, p 52.

51 RJ Walker, Colonisation and Development of the Maori People in Ethnicity and Nation-Building in the Pacific (1989; ed Howard) pp 157-58.

52 S Parker, 'The Maori Embrace Capitalism: Mabo - The Way Ahead' Australian Financial Review, 2 Sept 1993, p 9.

53 Te Puni Kokiri, op cit n 38, 18.

54 Te Puni Kokiri, Te Ture Whenua Maori Act 1993: A Working Guide to the Act (1993) p 7.

55 Putea, Whanau, Ahu Whenua, Whenua Topu, and Kai Tiaki. Ibid, p 30. Detailed descriptions of the various trusts as well as step-by-step instructions on formation of trusts and incorporations are found in the New Zealand government publications by the Ministry of Maori Development, supra nn 38, p 54.

56 Te Puni Kokiri, supra n 38, p 31.

57 Te Puni Kokiri, supra n 54, p 8.

58 Bank of Hawaii, supra $\mathrm{n} 31, \mathrm{p} 8$.

59 N Douglas, '100th Special Issue: Fiji' Pacific, Jan/Feb 1993, p 26.

60 S Robinson and J Dyall, Maori Sources - An Overview (1992) (unpublished report prepared for the New Zealand Government, on file with the authors).

61 Entitlement to own land in the Republic of the Marshall Islands is based on citizenship. 24 Marshall Islands Rev Code (1988), Chap 1. The Citizenship Act 1984 also allows for adopted and naturalized citizens with certain conditions. 43 Marshall Islands Rev Code (1988), Chap 4.

62 By the Land and Titles (Amendment) Act 1977 of the Solomon Islands, freehold ownership is restricted to persons with at least two grandparents born in the Solomon Islands. Solomon Islands Const, §§ 110-111.

63 Communal land may be alienated only to persons with more than one-half native blood and, in addition, requires consent of the Governor. Am Samoa Code, Title 37, Chap 1.

64 Under the Cook Islands Act 1915 (NZ), customary land is that land which 'being vested in the Crown is held by Natives or the desecendants of Natives under Native customs and usages of the Cook Islands'. I Adzoxornu, The Cook Islands in South Pacific Islands Legal Systems, (1993; ed Ntumy) pp 18-19.

65 lbid, $\mathrm{p} 19$.

66 JG Zorn, The Federated States of Micronesia in South Pacific Islands Legal Systems, (1993; ed Ntumy) p 499.

67 lbid.

68 lbid.

69 Investor's Guide to the Federated States of Micronesia (1989) p 16.

70 RMI Const Art X, S I(2). However, with approval of traditional leaders, customary land may be mortgaged to government agencies. Upon foreclosure, it is arguable under current wording of the relevant statute that non-citizens may purchase land at public auction. JG Zorn, The Republic of the Marshall Islands in South Pacific Islands Legal Systems, (1993; ed Ntumy) p 127.

71 lbid.

72 Kabua v Kwajalein Atoll Corp, Civ Act No 1984-102 (1985).

73 'Mexico: Rural Revolution' The Economist, 13 Feb 1993, p 12. Between 1917 and 1991, the Mexican Government confiscated 246 million acres for conversion to ejido lands. WR Smith, 'Salinas Prepares Mexican Agriculture for Free Trade' Mexico Trade and Law Reporter, 1 Oct 1992, at n 3. 
74 Ibid.

75 SK Shwedel and K Haley, 'Foreign Investment in the Mexican Food System' Business Mexico Jan/Feb 1992.

76 lbid.

77 VA Vilaplana, 'The Forbidden Zones in Mexico' (1973) 10 California Western Law Review 47, at p 48. 'Under no conditions may foreigners direct dominion over land and waters located within 100 kilometers of the borders and 50 kilometers of the coasts.' Ibid, p 49.

78 lbid, pp 60-62.

79 Ibid, p 61.

80 Am Samoa Rev Const Article I, $\S 3$.

81 ASCA 37.0204 (b).

82 Ibid.

83 M Eastly, '100th Issue Special Report: American Samoa' Pacific, July/Aug 1993, p 36.

$84 \mathrm{Ibid}, \mathrm{p} 37$.

85 Craddick and Craddick v Territorial Registrar of American Samoa (1980) 1 ASR2d 10, at p 13.

86 Haleck v Lee (1964) 4 ASR 519, at p 551.

87 Wabol v Villacrusis 958 F 2d 1450, 1461 (9th Cir 1990).

88 IA Martinez, 'Trust and the Civil Law' (1982) 42 Louisiana Law Review 1709.

89 R Batiza, 'The Evolution of the Fideicomiso (Trust) Concept Under Mexican Law' (1957) 11 Miami Law Quarterly 479.

90 Vilapana, op cit n 77, p 63.

91 lbid, $\mathrm{p} 64$.

92 An analysis of historical judicial opinions on the subject can be found in Batiza, op cit $\mathbf{n} 89$.

93 Vilaplana, op cit n 77, p 53.

94 A Winsor, The Complete Guide to Doing Business in Mexico (1994) p 86.

95 Vilaplana, op cit n 77, pp 54-55.

96 Ibid.

97 Ley para Promover la Inversion Mexicana y Regular la Inversion Extranjera (The Law to Promote Mexican Investment and Regulate Foreign Investment), Diario Official, 9 Mar 1973.

98 A Carillo, Note, 'The New Mexican Revolution: Economic Reform and the 1989 Regulations of the Law for the Promotion of Mexican Investment and the Regulation of Foreign Investment' (1991) 24 George Washington Journal of International Law and Economics 647, at p 676.

99 Ibid.

$100 \mathrm{lbid}, \mathrm{p} 677$.

101 Reglamento de la Ley para Promover la Inversion Mexicana y Regular la Inversion Extrajera (Regulation of the Law for the Promotion of Mexican Investment and the Regulation of Foreign Investment), Diario Official, 16 May 1989.

102 JH Kepner, Jr, 'Mexico's New Foreign Investment Regulations: A Legal Analysis' (1992) 18 Syracuse Journal of International Law and Economics 41, at p 56.

103 HH Camp, Jr et al, Foreign Investment in Mexico from the Perspective of the Foreign Investor, (1993) 24 St Mary's Law Journal 775, at p 796.

104 Winsor, op cit n 94, p 86.

105 North American Free Trade Agreement Between The Government of The United States Of America, The Government of Canada and The Government of The United Mexican States, Annex I, Schedule of Mexico states in part:

Foreign nationals, foreign enterprises or Mexican enterprises may acquire 'Certificados de Participacion Inmobilaria' (CPIs). CPIs grant the beneficiaries the right to use and enjoy property and to receive the profits that it may obtain from the profitable use of property. CPIs are issued by a Mexican credit institution that has been granted authorization to acquire through trust the title to real estate intended for industrial and tourism activities in the Restricted Zone for a period not to exceed 30 years.

The trust is renewable if, inter alia, the beneficiaries are the same and terms and conditions remain the same. Ibid.

106 Shwedel and Haley, op cit $\mathrm{n} 75$.

107 lbid.

108 In re Estate of McGaughey (1978) 60 Ill App 3d 150,376 NE 2d 259. However, in recent cases involving strict liability of 'owners' under the Comprehensive Environmental Response, Compensation and Liability Act of 1980 (CERCLA) there has been an interesting conflict of judicial opinion where land trusts are involved. In Illinois, a federal district court assessed no liability to trustees as owners under CERCLA even though the 
trustees held legal title. United States v Petersen Sand and Gravel, Inc 806 F Supp 1346 (ND Ill 1992). In an Arizona case, however, the court held there was CERCLA liability if the trustee had the 'power to control the use of trust property.' City of Phoenix v Garbage Services Corporation 827 F Supp 600, 605 (D Ariz 1993).

109 HW Kenoe, Kenoe on Land Trusts (1989) S 1.3. See also In Re Estate of Crooks, Jr v Hendricks 638 NE 2d 729 (Ill Ct App 1994).

110 Kenoe, supra note 109, S 1.5.

111 An excellent and thorough discussion of the Hawaii Land Trust in practice is found in CM Lee, 'What You Need to Know About the Hawaii Land Trust' The Hawaiian Realtor, Oct 1983, p 12.

112 'Where a transfer of property is made to one person and the purchase price is paid by another, a resulting trust arises in favor of the person by whom the purchase price is made, except as stated in SS 441,442 , and 444 .' Restatement (Second) of Trusts S 440 (1959).

113 Aldan-pierce v Mafnas No 89-003, slip op. p 9 (NMI July 5, 1991), vacated, 11 F.3d 923 (9th Cir. 1993).

114 Ferreira v Bona No 90-047, slip op. (NMI Feb. 18, 1992), vacated, 1 F.3d 960 (9th Cir. 1993).

115 Ibid, slip op. at 8.

116 Ferreira v Bona 1 F.3d 960, 963 (9th Cir. 1993).

117 lbid, slip op. at $\mathbf{p} 5$.

118 Ibid, slip op. at $\mathrm{p} 4$.

119 Land Trustee as Creditor Act (1982), Il. Stat. Ch 765, Act 415.

120 In the opinion of one legal authority who was asked to give advice on possible solutions to on-going problems in the CNMI, more important than the actual trust or other device is the setting forth of exactly what detailed provisions the legislature and judiciary would find permissible such as 'repair of the land upon termination' and 'no further development' clauses. Telephone interview with Prof. E C Halbach, Jr, Reporter for Restatement (Third) of Trusts (2 July 1994).

121 SSC Rep No 8-63, Eighth Northern Marianas Commonwealth Legislature, 2-4 (1993).

122 CNMI Public Law No 8-32 (1993).

123 Telephone interview with Ted Mitchell, plaintiffs' attorney based in Saipan (14 July 1994).

124 Telephone interview with Lt Gov Jesse Borja, CNMI (6 July 1994).

125 lbid. 